\title{
Openbaring as principium theologiae
}

\author{
M.A. Kruger \\ Dept. Nuwe Testament en Grieks \\ Hammanskraalse Teologiese Skool \\ Potchefstroomse Universiteit vir $\mathrm{CHO}$
}

\begin{abstract}
Theological renewal regarding differcnt theological disciplines as well as the complete theological encyclopedia has lately been debated worldwide. Likewise, the Reformed Churches in South Africa are in a process of reconsidering the traditional refonmed theological encyclopedia. This task can, however, not be fulfilled unless the basic issues are not also reconsidered. This article focuses on revelation as the principium theologice. The line of argumentation centres round the fundamental confession in anicle 2 of the Bclgion Confession. The truth implicit in this anicle, and accepted by the Reformed Churches, stresses that God can be known through his creation, sustenance and goveniment of the universe, but He can be known more convincingly by studving holy Scripture. To prove this point of departure, Romans 1.4 and Romans 10 are discussed. The distinction between special and gencral revelation, contextual theology and the relotionship to world religions and $H$. Bavinck's concept of the principium theologiae are also considered.
\end{abstract}

\section{INLEIDING}

Herbesinning oor teologie as wetenskap kom vandag wêreldwyd voor. Verskeie vrae kom in dié proses na vore: Is die tradisionele paradigmas nog voldoende om teologie te beoefen? Is die teologie genoegsaam prakties gerig? Is teologie genoegsaam in diens van die kerk? Wat is die veld, bron of principium van teologie?

In hierdie artikel word veral aandag gegee aan laasgenoemde vraag. Tradisioneel het die Gereformeerde teologie in die praktyk aanvaar dat die principium theologiae die Skrif is. Die vraag kan egter gestel word waarom die Skrif alleen as principium theologiae aanvaar word as die NGB stel dat deur die skepping, onderhouding en regering van alle dinge God reeds genoegsaam geken kan word om die mens te oortuig.

Die doel met hierdie artikel is nie om die totale omvang van die probleem te dek nie, maar eerder om diskussie te stimuleer deur die tradisionele Gereformeerde standpunt te bevraagteken vanuit Romeine, die Nederlandse Geloofsbelydenis en latere moderne probleme soos kontekstualisering en die standpunt oor wêreldgodsdienste. Daar sal dus nie gepoog word om alle teologiese denkrigtings oor dié onderwerp te behandel nie, - omdat so iets vanselfsprekend nie binne die omvang van 'n artikel gedoen kan word nie. 


\section{DIE SKRIF AS PRIMERE BRON}

Met die geloofsveronderstelling dat die Skrif die openbaring van God is, behoort eerstens na die Skrif teruggegaan te word om vas te stel wat die principium theologiae is. Vir hierdie doel gaan aandag gegee word aan die interpretasie van Romeine 1:184:23 en Romeine 10 sover dit openbaring raak, maar sonder om volledig op alle aspekte in te gaan. Detail-eksegese en dialoog met ander eksegete word nie hier gegee nie, maar kan sover dit Romeine 1-4 betref, gevind word in Openbaring, geloof en geregtigheid (Kruger, 1983) en sover dit Romeine 10 betref, in Naby jou is die woord! Romeine 10:8 (Kruger, 1988).

Die rede vir die keuse van hierdie twee gedeeltes is omdat Romeine 1-4 handel oor die verskillende vorms van openbaring wat God aan die mens gee en Romeine 10 oor die openbaring wat die Jode, wat Christus verwerp, alle verontskuldiging ontneem. Elders in die Skrif, byvoorbeeld in Psalm 19, word ook gehandel oor die tweërlei openbaring, naamlik die openbaring in die natuur en die openbaring in die woord, maar Paulus het hierdie beginsels verwerk in Romeine 1-4 en 10.

Die resultaat van die eksegese wat hieronder gegee word, verskil in een opsig aanmerklik van alle ander eksegete. Die skopus van Romeine 1-4 (sommige baken dit anders af) is nie om te bewys dat alle mense, heidene sowel as Jode, sondig is nie. Waarom sou Paulus soveel moeite doen om so 'n vanselfsprekendheid aan die gemeente in Rome so uitvoerig te beredeneer? Die sentrale boodskap in hierdie gedeelte is dat sommige mense, Jode sowel as nie-Jode, uit die totaal van die sondige mensheid, God se openbaring verwerp, hoewel geen mens dit kan bekostig nie (Kruger, 1983:101-117; 354-356). Romeine 1:18-32 handel oor sowel heidene as Jode (Kruger, 1983:101-135). Romeine 2:1-3:8 is 'n betoog van Paulus dat sommige Jode net soos baie heidene onderdrukkers van God se waarheid of openbaring is (Kruger, 1983:136-224). Daar is in baie kleiner aspekte ook verskille met ander eksegete. Meestal is hierdie verskille daaraan toe te skryf dat doelbewus probeer is om die primère bron, Romeine, te bestudeer sonder die bęlading wat deur die tradisie sedert die Reformasie daartoe bygevoeg is.

\subsection{Romeine 1-4}

Wanneer Romeine nie gelees word deur die bril van die konflik Luther teen Rome nie, kom verrassende nuwe aspekte na vore. Die aspekte van die Reformatore se beskouing van Romeine waarop 'n ander standpunt as dié van die Rooms-Katolieke ingeneem is, bly steeds belangrik, maar die spektrum van Romeine is wyer as dit. Romeine is egter veels te lank as 'n christianae religionis compendium (Donfried, 1991:xli) gesien 
wat nie aan die adres van die toenmalige lesers in die eerste plek gerig is nie.

Die doel is nie om in hierdie artikel detail-eksegese te gee nie: daardeur word 'n mens baie maklik verstrik in besonderhede en die groot lyn van die hoofdeel word dan nie gesien nie. Die benaderingswyse in hierdie artikel is dat die logiese hooflyn gegee word in verband met die onderwerp openbaring as bron waardeur God geken word, en dus as principium theologiae.

Romeine 1:16-17 word steeds algemeen aanvaar as die brug vanaf die inleiding na die liggaam van die brief. Ter wille van aansluiting by die eerste hoofdeel, Romeine 1-4, is dit nodig om net weer hierdie twee verse onder oë te neem.

Nadat Paulus inleidend geskryf het van sy verlange om na Rome te kom en van sy roeping om die evangelie te verkondig, sluit hy in 1:16-17 aan by die woord evangelie wat hy reeds genoem het in $1: 1$ en wat weer in die infinitief $\in \dot{U} \alpha \gamma \gamma \in \lambda i \zeta \in \sigma \theta \alpha$ (om te evangeliseer) in die laaste vers voor 1:16-17 voorkom. Wanneer Paulus 'n uitbreiding invoeg in die formele briefbegin, beteken dit dat hierdie ingevoegde gedagte baie belangrik is en later in die brief meer aandag sal kry. Evangelie wat so prominent en vroeg ter sprake kom, is dus 'n sleutelwoord om 1:16-17 te verstaan.

Paulus sê dat hy hom nie skaam vir die evangelie nie. In $1: 1$ het hy hierdie uitgangspunt reeds gestel wat die evangelie van $G o d$ betref. Nou gaan hy verder deur te sê dat die evangelie 'n krag van God is tot redding vir elkeen wat glo. Hierdie "elkeen" word dan verder beskryf in 'n rangorde: eerste Jode en dan nie-Jode. Dit kom egter daarop neer dat die evangelie 'n krag van God is wat elkeen, uit watter volk ook al, red indien 'n persoon glo.

Paulus beskryf dan in 1:17 waarom die evangelie so ' $\mathrm{k}$ krag van God is: in die evangelie word iets geopenbaar, naamlik die geregtigheid van God. Geregtigheid moet hier sterk verbind word aan die Persoon van Christus (vgl. 1 Kor. 1:30). Dit is hierdie geregtigheid van God wat die krag is wat red. Hierdie geregtigheid word egter net 'n mens se deel as jy glo. Uit geloof ontvang 'n mens geregtigheid, maar dit lei dan ook tot ' $n$ volhardende geloof - ' $n$ feit wat Paulus bevestig met ' $n$ aanhaling uit Habakuk 2:4. Iemand wat 'n regverdige is, dit wil sê wat geregtigheid het, sal lewe uit sy geloof.

Wat egter belangrik is in verband met openbaring is dat Paulus sê dat in die evangelie iets - God se krag tot redding - geopenbaar word.

Nou gaan Paulus verder: in Romeine 1:18 tot 3:31 word gehandel oor verskillende vorme van openbaring wat God gebruik het om mense tot geloof te bring. Die drie openbaringsvorme wat Paulus behandel, is dus evangelie. Hierdie verskillende vorme 
van openbaring wat genoem word, is een van die aspekte wat nie in die stryd tussen die Reformasie en Rome duidelik uitgespel is nie. Om dit duidelik te kan sien, moet in die eerste plek gelet word op die wyse waarop Romeine 1:18 aansluit by Romeine 1:16-17.

Romeine 1:18 funksioneer as 'n opskrif vir Romeine 1:18 tot 4:23. In 1:19-32 toon Paulus aan dat daar mense uit alle volke is wat die waarheid in ongeregtigheid onderdruk en oor wie die toorn kom. In 2:1 tot 3:8 oortuig hy 'n ongehoorsame Jood dat ook hy die waarheid in ongeregtigheid onderdruk en dat hy dieselfde oordeel moet verwag. In 3:9-20 toon hy aan dat niemand kan bekostig om die openbaring te onderdruk nie. Hoofstuk 3:21-31 handel oor die hoogste openbaring van God, naamlik in Christus, met die implisiete waarskuwing dat as dit verwerp word, God se toorn oor die onderdrukker sal kom. Hoofstuk 4:1-23 belig Abraham as die groot voorbeeld van iemand wat die openbaring gelowig aangeneem het. Oor sulke mense kom die toorn van God nie.

In Romeine 1:18-32 gebruik Paulus weer dieselfde werkwoord wat in 1:17 gebruik word, naamlik word geopenbaar. In 1:17 was dit die geregtigheid van God, dus 'n reddingskrag, wat geopenbaar word. In 1:18 is dit God se toorn wat geopenbaar word - die werkwoordvorm wat gebruik word is die praesens. Hierdie toorn word vanuit die hemel geopenbaar. Calvyn (1959:68) sê dat nie soseer rigting hier aangedui word nie as die geweldigheid van die toorn. Later word dit duideliker hoe dit gebeur (1:24, 26, 28)..

Dis egter baie belangrik om te let op wie hierdie toorn gerig word. Tradisioneel is aangeneem dat die toorn op alle mense gerig word omdat hulle sondig is. Die onderskeid is gemaak dat daar in 1:18-32 van toorn op die heidene sprake is en vanaf 2:1 (sommige sê 2:17) van toorn op die Jode. Hierdie onderskeiding is reeds grootliks prysgegee in latere Bybelvertalings, in sover 1:18-32 nie meer as opskrif het dat dit handel oor God se toorn oor die heidene nie (kyk ook Morris, 1988:74). Daar is egter nog 'n belangrike onderskeiding wat gemaak moet word.

Romeine 1:18 sê letterlik dat God se toorn geopenbaar word oor dié mense wat die waarheid (openbaring) in (of deur) ongeregtigheid onderdruk. Hierdie stelling moet as beperkend en beskrywend opgeneem word. Hierdie stelling gaan nie oor alle mense nie; diegene wat Paulus bedoel, is beperk tot die onderdrukkers van God se waarheid. Hulle word beskryf as diegene wat God se waarheid nie aanvaar (met geloof en vertroue op Hom) nie, maar dit verwerp. Romeine 1:18 bedoel ook letterlik wat daar staan: hierdie soort mense en nie heidene nie. Hierdie omskrywing sluit Jode in. In hoofstuk 4 sluit Paulus hierdie eerste gedeelte van Romeine af met die groot voorbeeld van iemand op wie die toorn van God nie kom nie - Abraham. Abraham word as voorbeeld voorgehou want hy is een wat nie God se waarheid onderdruk het nie, maar 
dit met volle geloof en vertroue aanvaar het.

Romeine 1:19 begin nou uitspel watter waarheid (openbaring, evangelie) dit is wat sommige mense onderdruk het. In hierdie vers begin Paulus nou handel oor die eerste soort openbaring wat God gee. Hierna sal hy nog twee ander soorte noem.

Die waarheid wat onderdruk word is die onsigbare dinge (soos sy ewige krag en goddelikheid) wat van God geken kan word. Hierdie dinge is in hulle en onder hulle openbaar. God openbaar die waarheid aan alle mense en dus ook aan hierdie mense wat dit onderdruk. In die tweede deel van 1:19 word 'n uitsonderlike stelling gemaak: God het dit tot hulle voordeel aan hulle geopenbaar. Die persoonlike openbaringsdaad van God ter voordeel van alle mense word dus beklemtoon. Dis die evangelie wat 'n krag tot redding is vir elkeen wat glo.

Vers 20 beskryf hierdie openbaring verder. Die onsigbare dinge, naamlik sy ewige krag en goddelikheid, kan van die begin van die skepping af waargeneem en duidelik gesien word. Die gevolg van hierdie waarneming is dat niemand 'n verontskuldiging het as hy God nie eer nie. Die feit is dat 'n deel van die mensheid God leer ken het

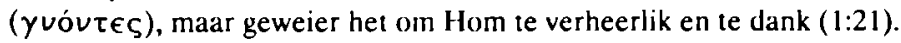

Wat ons in Romeine 1:19 tot 1:21 het, is wat gewoonlik die algemene openbaring genoem word. Hierdie benaming lei egter tot misverstand - waaroor later.

Romeine 1:18-32 handel oor mense wat die openbaring van God onderdruk in plaas daarvan om gelowig daarop te reageer. Hierdie mense sluit Jode en nie-Jode in en is diegene wat die evangelie verwerp wat tot hulle redding kon dien.

Vanaf 2:1 begin Paulus handel met 'n fiktiewe, ongehoorsame Jood wat homself nie geag het as ingesluit by die onderdrukkers van God se openbaring nie. Die sondes wat in 1:23-28 genoem word, kom wel meer by die heidene voor, maar sommige Jode het hulleself dwarsdeur die verbondsgeskiedenis ook daaraan skuldig gemaak. Paulus

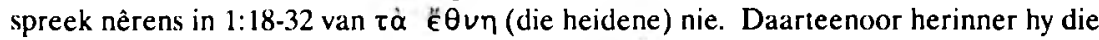
Jood wat hy vanaf $2: 1$ aanspreek met die vokatief $\alpha \nu \theta \rho \omega \pi \epsilon(0$, mens), dat hy ingesluit was by die $\dot{\alpha} \nu \theta \rho \dot{\omega} \pi \omega \nu$ van 1:18. Hierdie kategorie Jode se onderdrukking van die openbaring was juis dat hulle van die wet 'n verdienstesaak gaan maak het en dit ontledig het van die absolute oorgawe aan God en vertroue op Hom alleen vir redding. In die hele gedeelte van 2:1 tot 3:8 handel Paulus nou met die ongehoorsame Jode wat hulle deur besnydenis en verbond ag as mense oor wie God se toorn nie geopenbaar kan word nie. Teen die einde van hierdie gedeelte vra Paulus wat dan eintlik die voordeel van 'n Jood of die nut van die besnydenis is. Hy antwoord self dat hulle groot 


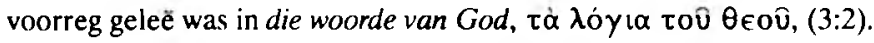

"Die woorde van God" is die tweede soort openbaring van God, naamlik dit wat die Jode alleen ontvang het. Hierdie bykomende openbaring van God aan hulle was groter genade aan die Jode. Hierdie openbaring is die woord-openbaring van God aan sy

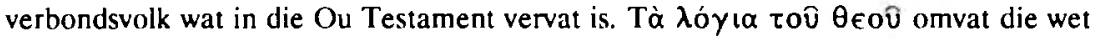
en profete, die hele Ou Testament, in sy mondelinge verkondiging en in sover dit opgeskryf was.

Romeine 1:18-3:8 dra dus hierdie boodskap: die toorn van God kom oor alle mense wat sy openbaring onderdruk. Die toorn word gerig op die heidene wat die openbaring wat sedert die skepping voortduur, ontvang en onderdruk het. Die toorn kom ook oor die Jode wat hierdie openbaring, sowel as die groter genade van God se woorde aan die verbondsvolk ontvang en onderdruk het. Tradisioneel is aangeneem dat hierdie gedeelte die boodskap dra dat die toorn van God oor alle mense kom omdat hulle sondig is. Paulus se doel was egter nie om te bewys dat alle mense sondig is nie. Die standpunt wat hy wil tuisbring is juis dit: uit die ganse sondige mensheid (Rom. 3:9-20) is daar werklik onderdrukkers van sy waarheid (1:18-3:8) wat God se groter genade tot nulle redding verwerp.

Wanneer Romeine 3:9-20 vervolgens handel oor die feit dat alle mense skuldig is, is die boodskap: hoe kan mense bekostig om God se openbaring te verwerp as hulle skuldig staan voor Hom? God kom hulle dan juis ondanks hulle sonde met sy openbaring tot redding.

Nadat Paulus die twee soorte openbaring en mense se reaksie daarop behandel het, kom hy in Romeine 3:21 met die derde soort openbaring wat aangekondig word met ' $n$ kragtige vuvi $\delta \dot{e ́}-$ maar nou. Die toorn van God kom oor diegene wat sy openbaring verwerp, maar God kom egter nou in sy groot genade en liefde met die klimaks van alle self-bekendmaking.

Paulus verwys terug na die woord geregtigheid in 1:17. God openbaar hierdie geregtigheid (Christus) waaroor die wet en die profete getuig.

Samevattend kan gesê word dat Paulus dus in 1:18 tot 3:31 handel oor die drie stappe van God se openbaring waarby telkens groter genade van God betoon word aan sondige mense. Hierdie groter genade bring egter ook mee dat daar groter skuld is by verwerping daarvan en dat die toorn van God met meer krag sal kom oor hulle wat sy openbaring verwerp. 


\subsection{Romeine 10}

In Romeine 10 werp Paulus weer eens lig op God se openbaring. Hierdie gedeelte is deel van die hoofdeel Romeine 9-11 waarin Paulus handel oor die Jode wat die Christus verwerp.

Hierdie gedeelte waarin Paulus oor openbaring praat, begin in 9:30 waar hy hom weer uitspreek oor geregtigheid soos reeds in 1:16-17. Hy vra of ons dan die gevolgtrekking moet maak dat die heidene wat die geregtigheid nie nagejaag het nie, dit verkry het maar die Jode wat dit nagejaag het, het dit nie verkry nie. Hy toon egter ook onmiddellik die rede waarom dit wel so is. Die heidene het die geregtigheid wat uit die geloof is, ontvang - dit is die geregtigheid wat voortspruit uit die gelowige aanvaarding van God se openbaring. Maar hierdie geregtigheid het die ongehoorsame Jode nie gekry nie, omdat hulle dit nie deur die geloof wou ontvang nie, maar deur werke. Hulle het hulle gestamp teen die struikelblok. Wat was hierdie struikelblok? Dat die wet en profete nie gevra het vir werke nie, maar ten diepste vir geloof. Paulus toon vervolgens in 10:4 aan dat die $\tau \dot{\epsilon} \lambda{ }_{\zeta}$ van die wet Christus was. Die

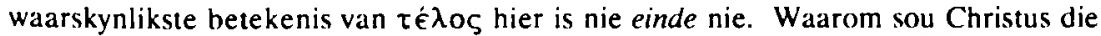
einde van die wet wees? So 'n uitleg kan net aangeneem word deur die Lutherse dichotomie tussen wet en evangelie te aanvaar. Die woord moet eerder gesien word in verband met die werkwoord $\tau \epsilon \lambda \hat{\epsilon} \omega$ wat Paulus al in 2:27 gebruik het en wat beteken dat die wet ten diepste vervul word (vgl. ook Edwards, 1992:249-250).

Wie dus die wet en die profete gelowig aanvaar het met vertrouende oorgawe aan God, het eintlik vertrou op Christus, want in Hom word die wet vervul.

In Romeine 10:5 lees ons dat Moses van die geregtigheid wat uit die wet is, sê dat die een wat die wet doen daardeur sal lewe. Hierdie doen moet ernstig, maar ook reg verstaan word. Paulus sê dieselfde in Galasiërs 3:12. Om te doen, beteken nie om gebod op gebod en reël op reël te hou nie, maar dat met geloof gereageer word op God se openbaring in die wet en profete.

Nou gaan Paulus verder in 10:6 deur te sê wat die houding is van iemand wat geregtigheid uit geloof ontvang. So iemand vra nie wie die onmoontlike sal doen nie (10:7); hy weet dat die woord van God naby is. Die woord wat roep tot geloof is naby. Dit is ook die woord wat roep tot Christus.

Maar wat is hierdie woord wat naby is? Paulus gebruik hier Deuteronomium 9:4 en $30: 12-14$. Hy sê dit is die woord wat hy verkondig. Dit is dus die mondeling verkondigde evangelie, maar dit is egter ook die verkondiging van God se hele openharing, van God se evangelie (1:1) van die begin af. Elkeen wat God aanroep, sal 
gered word. Maar hoe sal hulle Hom aanroep in wie hulle nie geglo het nie? 'n Mens roep God aan omdat jy in Hom glo. Maar hoe kan hulle glo as hulle nie van Hom gehoor het nie? Hoe kan hulle hoor sonder iemand wat verkondig? Hoe sal iemand verkondig as hy nie gestuur is nie? Maar tog het almal nie die evangelie gehoorsaam nie. Die geloof is uit die gehoor en die gehoor is deur die woord van Christus.

Paulus stel bogenoemde vrae asof dit die woorde is van iemand wat die ongehoorsame en ongelowige Jode wil verskoon: het hulle miskien nie gehoor nie? Dit kon tog wees dat sommige Jode nie die openbaring genoegsaam gehoor het nie. Op hierdie vrae kom dan die byna skokkende antwoord met 'n aanhaling uit Psalm 19:5. Geen mens kan sê dat hy nie voldoende openbaring ontvang het nie. Reeds deur die openbaring wat voortduur sedert die skepping (Rom. 1:20) het ook die Jode genoegsaam openbaring gehad sodat hulle hul met geloof op God kan werp. Die skepping dien as een van die verkondigers en Paulus as ' $n$ ander. Hoe sou die Jode hulle dan, in die lig daarvan dat hulle nog meer gekry het as die heidene, kan verontskuldig dat hulle nie gehoor het nie?

Wat hier opmerklik is, is dat Paulus dus die openbaring van God in die skepping, onderhouding en regering van alle dinge sedert die skepping, beskou as een van die verkondigers (10:18). Hy trek die konsekwensie van God se liefdevolle openbaring só deur dat geen mens onskuldig kan pleit deur te sê dat hy nie voldoende openbaring ontvang het nie.

Verskillende sake word hier duidelik. Volgens 10:8 kan daar nie sommer 'n gelykaanteken geplaas word tussen woord en Skrif nie. Die openbaring van God omring die mens as 't ware elke oomblik. Hierdie openbaring is genoegsaam om iemand tot redding te lei. Verkondigers van God se evangelie is nie slegs mense nie, maar ook ander skeppingsmiddele wat sy onsigbare dinge, sy ewige krag en Godheid aan die mense kommunikeer. God is persoonlik teenwoordig agter alle openbaring (Rom. $1: 19)$.

\section{DIE ONDERSKEIDING ALGEMENE EN BESONDERE OPENBARING}

Berkhof (1973:78) sê dat algemene openbaring meestal verstaan word as die openbaring wat nie op ' $n$ besondere daad van God berus nie, maar reeds in die verhouding van die mens tot die skepping gegee is. Verder is die algemene openbaring ook 'n openbaring wat oral en altyd aan alle mense gegee is. Besondere openbaring word gewoonlik verstaan as iets wat op 'n besondere daad van God berus, soos die openbaring wat alleen tot besondere enkelinge of groepe kom. Hierby word dan gedink aan die openbaring aan Israel, in Christus, in die Bybel en deur die kerk. 
Calvyn het in sy Institusie waar hy uitvoerig handel oor die kennis van God die Skepper, nêrens die term algemene openbaring gebruik nie, alhoewel hy dit wat daarmee bedoel word, duidelik omskryf in veral I 3:1-3 en I 5:1-15. In I 3:1-3 handel hy oor die ingeplante kennis van God wat in elke mens is. God het aan elke mens 'n sekere begrip van sy Godheid gegee en Hy vernuwe die kennis steeds sodat elkeen deur sy eie getuienis veroordeel word as hy God nie erken nie. Calvyn kom tot die gevolgtrekking aangaande hierdie ingeplante kennis dat selfs by die goddelose dit 'n feit is dat ' $n$ sekere kennis van God altyd in die harte van alle mense kragtig lewe (I 3:2).

Die persoonlike van hierdie openbaring word deur Calvyn duidelik bely. Dis God self wat persoonlik hierdie kennis in elke mens plant (I 3:1). Hierdie belydenis stem volledig ooreen met Romeine 1:19b waar ook gestel word dat die openbaring sedert die begin van die skepping 'n persoonlike daad van God is.

Calvyn onderskei verder die kennis wat God gee in aangebore of ingegewe kennis, die kennis vanuit die bou en bestier van die wêreld, die kennis van God vanuit die mens as wonderwerk van God se skepping self en die kennis van God deur katastrofale gebeure (I 5:1-8). (Dis opmerklik dat Calvyn in hierdie deel van sy teologie ruim gebruik maak van die openbaring in die skepping, onderhouding en regering van alle dinge saam met die Skrifopenbaring.) As hierdie kennis deur mense reg ontvang word, is dit nie leeg nie, maar vrugdraend. Hy verwys na Handelinge 17:27 as hy stel dat deur al hierdie openbaring God Hom naby ons bring (1 5:9). Verder leer hy dat die doel van hierdie openbaring is dat dit ons bring tot die diens van God en dat dit die hoop op die toekomstige lewe in ons opwek (I 5:10).

Wanneer Calvyn in I 6:1-4 skryf dat die Skrif nodig is om tot kennis van God die Skepper te kom, bedoel hy slegs om te sê dat weens die verdorwenheid en die moedswilligheid van die mense hulle nie deur die openbaring in die skepping, onderhouding en regering van alle dinge tot ware godsdiens kan kom nie. Vir geen oomblik betoog hy dat die openbaring in die skepping, onderhouding en regering van alle dinge onvoldoende is nie. Calvyn praat ongelukkig in hierdie gedeelte in die algemeen oor die mens, hoewel hy inhoudelik van Romeine 1:18 gebruik maak. Hy gebruik die gedagte van onderdrukking van die waarheid uit hierdie vers (I 5:4) asof Paulus van die hele mensheid praat.

Samevattend kan dus gestel word dat Calvyn geleer het dat mense God kan ken uit die openbaring in die skepping, onderhouding en regering van alle dinge sodat hulle Hom ook kan dien en eer. God het in die verdere openbaring Hom in sy liefde soveel heerliker en voller geopenbaar, hoewel die openbaring sedert die begin van die skepping reeds voldoende was. 
Die onderskeid van Godskennis uit die skepping, onderhouding en regering van alle dinge soos deur Calvyn geleer, en Godskennis uit die Skrif, het reeds vanaf die apostoliese vaders voorgekom. Dit is dus 'n erkenning van God se openbaring buite die Skrif om. Justinus die Martelaar, Tertullianus, Irenaeus, Augustinus, Damascenus en ander het hierdie twee tipes openharing onderskei en het ook aan die openbaring buite die Skrif om hoë waarde toegeken (Bavinck, 1928:I 273). Bavinck (1928:I 276) meen dat daar in hierdie tweërlei openbaring wat aanvaar is 'n sekere dualisme was en dat ook Calvyn daaraan nie ontkom het nie. Die dualisme het daarin bestaan dat 'n revelatio naturalis gestel is teenoor 'n revelatio supermaturalis. In die lig van Calvyn se klem op God se persoonlike bemoeienis, het Bavinck waarskynlik verkeerd geoordeel (vgl. Inst. I 3:1). Bavinck neem 'n sterk standpunt in as hy sê dat alle openbaring bonatuurlik is (1928:I 278). "Schepping, onderhouding en regeering zijn eene machtige, voortgaande openbaring Gods" (Bavinck, 1928:I 278). Van hierdie openbaring is die persoonlike, lewende en waaragtige God ook die subjek (Bavinck, 1928:I 311). Bavinck sê dan dat hierdie openbaring algemeen, op sigself waarneembaar en verstaanbaar is vir elke mens (1928:I 282). Hy verwerp dus die gedagte dat God minder betrokke is by wat hy noem die algemene openbaring. Bavinck tipeer hierdie soort openbaring as algemeen omdat alle mense dit waarneem en verstaan. In hierdie omskrywing is daar egter iets wat volgens Romeine $1: 19 \mathrm{~b}$ nie aanvaarbaar is nie: dit is die gedagte van deduktiewe kennis, naamlik dat die mens op 'n indirekte wyse aflei en dat God nie direk met hom kommunikeer nie. Volgens Romeine 1:19-21 is God net so persoonlik besig om met mense te kommunikeer in die openbaring buite die Skrif om as in die Skrif. Bavinck erken dit ook, maar is tog nie duidelik oor hierdie direk persoonlike spreke van God in die openbaring buite die Bybel nie.

Polman (1949:85) sê dat Paulus met "ronde woorden" verklaar dat die fundamentele openbaring (Polman se term vir algemene openbaring) nie genoegsaam is nie. Hy stel ook dat by die onwedergebore hart van die mens die fundamentele openbaring nooit sy doel bereik het nie. Dis duidelik dat Polman Paulus verkeerd verstaan het, ook wanneer hy beweer dat die fundamentele openbaring slegs die mens sy skuld ontneem. Verder, ook die Skrif kan nooit sy doel bereik by die onwedergebore hart nie. Waarom dan nie ook van die ongenoegsaamheid van die Skrif praat nie?

Berkhof het teologies vier punte van kritiek teen die onderskeiding tussen algemene en besondere openbaring. Eerstens meen hy dat die woord openbaring te sterk is vir die wyse waarop God Hom in sy skepping bekend maak. Hy wil eerder dink aan die beeld van 'n indirekte lig wat deur die ervaringswerklikheid heenstraal. Tweedens stel hy dat as openbaring ' $n$ ontmoetingsgebeure is waarin enkeling of groep ' $n$ besondere belewenis van die teenwoordigheid van God ervaar, algemene openharing dan 'n 
teenstelling in sigself is. Derdens kan nie gestel word dat die openbaring opgesluit is in die Ou en Nuwe Testament nie hoewel dit die hoogste en normatiewe openbaring is. Die openbaring in Christus is normatief maar nie eksklusief nie. Laasgenoemde twee tiperings kan nie uitruilbaar gebruik word nie. Vierdens suggereer die teenstelling algemeen-besonder'n breuk tussen die twee soorte openbaring. So 'n breuk kan nie aanvaar word nie (Berkhof, 1973:78-79).

Met die laaste drie van Berkhof se teologiese besware kan saamgestem word. Die eerste is egter in stryd met die persoonlike betrokkenheid van God by die openbaring buite die Skrif om soos geleer in Romeine 1:19b en Romeine 10:8-21.

Berkouwer weer handhaaf die begrip algemene openbaring en verdedig dit teen misbruik van die kant van die modernisme en liberalisme sowel as die Rooms. Katolieke gedagte van natuurlike teologie en natuurlike Godskennis. Hy verdedig dit ook teen rigtings waar die problematiek van die sonde nie geskei word van die soewereine openbaring van God nie (Berkouwer, 1951:272-273). Berkouwer handel egter nie oor teologiese besware soos wat Berkhof dit stel nie.

'n Onderskeid tussen hierdie twee soorte openbaring moet volgens die Skrif en volgens die kerk deur die eeue aanvaar word. Die benaming algemene en besondere openbaring kan egter nie aanvaar word nie. Hierdie onderskeiding laat nie reg geskied aan God se persoonlike, voortgaande, liefdevolle openbaring aan die kerk in sy voortgang in die geskiedenis, sowel as aan die wêreld wat nie die openbaring van die Skrif het nie. Mooneyham (1974:428) maak die stelling dat die handelinge van die Heilige Gees wat in Handelinge beskryf word, nie beteken dat die Heilige Gees toe met daardie werk na hoofstuk 28 opgehou het nie.

\section{KONTEKSTUEI E TEOI OGIE}

Wanneer besin word oor die verhouding tussen die Skrifopenbaring en die openbaring in die skepping, onderhouding en regering van alle dinge, is dit ook nodig om aandag te gee aan die kontekstuele teologie wat in die afgelope dekades 'n nuwe dimensie toegevoeg het aan hierdie probleem.

Nicholls (1988:164-166) gee 'n goeie beskrywing van die verskillende denkrigtings oor kontekstualisering. Met kontekstualisering kan verskillende nuanses aangedui word. Daar kan klem gelê word op die verhouding van die Skrif tot die menslike situasie in die sin dat gevra word wat die Skrif vandag vir die mense in 'n bepaalde konteks sê. In hierdie verband het kontekstualisering 'n sterk missiologiese waarde. Hierdie kontekstualisering kan oor kultuurgrense heen gaan of binne-kultureel wees. Die 
verskil in Paulus se metode van prediking in Antiogië in Pisidië (Hand. 13:16-41) en te Atene (Hand. 17:22-31) is 'n duidelike aanduiding van die sosiologiese en teologiese onafwendbaarheid van kontekstualisering.

Vanaf radikale kant word kontekstualisering vandag deur die teologie van bevryding of die teologie van revolusie gesien as eerstens 'n verwerping van die tradisionele opvatting oor openbaring soos in die Skrif vervat. Die woord van God kan volgens hulle nie gelykgestel word aan enige bepaalde vorm nie, hetsy die Skrif of teologiese sisteme. Hulle ontken dat die Skrif vaste waarhede bevat. Aangesien die Skrif kultureel en histories bepaald is, is sy boodskap relatief en situasioneel. Hulle beweer verder dat daar geen waarheid is buite die aktiwiteit van konkrete historiese gebeure van menslike stryd nie. Daar kan geen kenteoretiese verskil wees tussen gedagte en handeling, waarheid en praktyk nie; daarom moet alle outentieke teologie deelnemende teologie wees. Volgens die radikales kom teologiese kennis alleen van deelname in aksie en nadenke oor die praktyk; daarom begin teologie nie met die lees van die Skrif nie, maar met die lees van die tye, waar God besig is om te humaniseer en te bevry.

Teenoor die radikale opvatting van kontekstualisering soos gevind in die teologie van die revolusie, staan die konserwatiewe begrip daarvan. Te Lausanne (1974) en Bermuda (1978) is van evangeliese kant hieroor besin. Vir baie konserwatiewe teoloë is kontekstualisering beperk tot die getroue en relevante oorbring van die onveranderlike boodskap van die Bybel in die taal en kultuur van die ontvangers. Ander konserwatiewe teoloë wil verder gaan as bogenoemde. Hulle bly getrou aan die grammaties-historiese eksegese van die Bybel, maar kontekstualisering geskied volgens hulle alleen wanneer die betroubare eksegese in dialoog tree met die menslike situasie van die ontvanger. So 'n ontmoeting tussen die eksegese en die omgewing moet sowel teologies as eties wees en dit vind plaas onder leiding van die Heilige Gees wat teks en konteks verbind. Volgens hierdie benaderingswyse moet die eksegeet homself vereenselwig met die teks en hom dan daarvan distansieer en daaroor nadink. Op dieselfde wyse moet hy homself vereenselwig met die konteks, hom dan terugtrek daarvan en daaroor nadink. Outentieke kontekstualisering vind sogenaamd plaas wanneer hierdie twee horisonne ontmoet. Evangeliese teoloë sê egter dat kontekstualisering alleen kan plaasvind wanneer daar 'n egte bereidheid tot dissipelskap is. Ware kontekstualisering vereis ook lojaliteit aan die kerk en waarsku teen sinkretisme. Kontekstualisering kulmineer in die inbreek van die blye boodskap in elke situasie.

Uit hierdie tekening van Nicholls (1988:164-166) kan die gevolgtrekking gemaak word dat wie met die veronderstelling na die Skrif kom dat hy dit as die woord van God aanvaar, soos Jesus die Ou Testament aanvaar het, nie die radikale opvatting van 
kontekstualisering kan aanvaar nie. Die vraag is egter of in die lig van artikel 2 van die Nederlandse Geloofsbelydenis en die voortgaande openbaring van God die konserwatiewe opvatting van kontekstualisering as voldoende aanvaar kan word. Dit is wel goed dat die Skrif moet spreek vir die wêreld van vandag, maar moet die teologie nie ook die openbaring wat vandag nog voortgaan, volgens artikel 2 NGB en Romeine 1-4 en 10, laat spreek nie? Openbaring van God het nie net te doen met ons ewige heil nie, maar ook met die heil van die kerk en wêreld van dag tot dag. Die gevaar van subjektiwisme is groter as wanneer met die Bybelse openbaring teologie beoefen word. Moet 'n mens egter, om dié gevaar te ontkom, die roeping versaak? Pinnock (1988:586) meen dat as ons aanvaar dat daar ' $n$ basiese eenheid is tussen die twee soorte openbaring, dit aanvaar kan word dat iemand wat nie die Skrifopenbaring gekry het nie ook saligmakende geloof kan hê deur sy antwoord op die openbaring wat hy wel gehad het.

\section{OPENBARING IN DIE ANDER WêRELDGODSDIENSTE?}

Teenswoordig word daar weer van alle kante beweer dat die groot wêreldgodsdienste ook maar lei na God. God sou Homself daarin openbaar op so 'n wyse dat die aanhangers van die Hindoeïsme, Boeddhisme en ander wêreldgodsdienste langs die weg van hulle onderskeie godsdienste gered word. Hierdie tendens is geen nuwe ontwikkeling nie: reeds Troeltsch het beweer dat die Christendom tot dusver, dus nie noodwendig vir altyd nie, die hoogste vorm van godsdiens was (vgl. Kraemer, 1958:56). Troeltsch is later deur baie ander gevolg (o.a. Verkuyl, 1975:474-476). Vir sommige is alle menslike geskiedenis heilsgeskiedenis en is daar 'n konvergensie van religieë aan die ontwikkel (Verkuyl, 1975:475-476).

Dit is wel waar dat daar waarheidsmomente aanwesig is in ander religieë (Kraemer, 1958:72). Kraemer (1938:135-136) wys egter tereg daarop dat hierdie waarheidsmomente ingebed is in die godsdienssisteme wat in hulle totaliteit van God af weg gerig is.

Romeine 1 is hieroor ook baie duidelik. Hulle wat die waarheid van God onderdruk, wat dus sy openbaring verwerp (Rom. 1:18), gaan daartoe oor om afgode te aanbid (Rom. 1:23). Paulus stel dit duidelik in hierdie gedeelte (Rom. 1:18-32) dat die toorn van God rus op sulke mense.

Wanneer van kontekstuele teologie gepraat word waar erns gemaak word met God se voortgaande openbaring, kan dit hoegenaamd nie uitloop op 'n relativering van die ander godsdienste en die Christelike godsdiens nie. 


\section{PRINCIPIUM THEOLOGIAE BY BAVINCK}

Omdat dit onmoontlik is om binne die bestek van hierdie artikel die Rooms-Katolieke standpunt, die verskillende Lutherse standpunte en ander standpunte oor die principium theologiae te bespreek, word vervolgens net vanuit gereformeerde geledere die standpunt van Bavinck getoets.

Bavinck praat van drie principia. God is self die principium essendi van alle teologie in sover $\mathrm{Hy}$ die oorsprong is van alle geskapene, van die wetenskap en meer bepaald ook van teologie (Bavinck, 1928:I 183).

Die principium cognoscendi van teologie is God se openbaring, wat Bavinck eers heel in die algemeen stel (1928:I 184). Hierdie principium cognoscendi van die teologie is God se selfopenbaring of selfmededeling aan sy skepsels.

Derdens is daar die principium cognoscendi internum. Die selfopenbaring van God, sy selfmededeling aan mense, is eintlik die principium cognoscendi externum. Die Heilige Gees is egter die innerlike werker wat mense innerlik verlig (1928:185).

Wanneer Bavinck by die principium cognoscendi externum meedeel dat hy hier nog praat van openbaring heel in die algemeen, is dit duidelik dat hy 'n beperking daarop wil plaas. Hierdie beperking gee hy wanneer hy handel oor die verhouding tussen Skrif en openbaring. In ooreenstemming met die vleeswording van Christus argumenteer hy dat daar ook 'n vleeswording van die openbaring plaasgevind het, naamlik dat die woord Skrif geword het. Hierby vermeld hy dan die verskil tussen teopneustie en openbaring. Nie alle openbaring het Skrif geword deur teopneustie nie. Tog val openbaring en teopneustie in baie gevalle saam. Hy wys dan twee rigtings as te eensydig af: eerstens diegene wat openbaring ten gunste van die Skrif wil inperk en tweedens diegene wat die Skrif misken ten gunste van die openbaring. Die juiste opvatting is dat die Skrif nie van die openbaring losgemaak kan word nie en ook nie daarmee vereenselwig kan word nie (Bavinck, 1928:352-354).

Wat beteken hierdie onderskeiding egter vir Bavinck? Hy stel dit soos volg: "De openbaring bestaat voor ons, voor de kerk aller eeuwen, slechts in den vorm der Heilige Schrift." Hy (1928:345) gaan dan so ver dat hy stel dat daar geen gemeenskap met Christus is as alleen deur gemeenskap met die woord van die apostels nie: Johannes 17:20, 21, 1 Johannes 1:3.

Bavinck het tot hierdie gevolgtrekking gekom via sy parallelisme van die Skrif wat die vleeswording van die Woord is. Sy uitspraak oor die gemeenskap met Christus wat 
alleen moontlik kan wees deur gemeenskap met die apostoliese woord is egter direk in botsing met wat Paulus leer in Romeine 1:18-21 en Romeine 10. As dit waar moes wees, sou Abraham geen deel aan Christus gehad het nie en Melgisedek sou nie priester van God kon wees nie.

Openbaring is deur Bavinck te eensydig soteriologies gesien. Reeds in die Ou Testament is daar veel in veral die Profete wat fokus op hierdie lewe sonder dat die soteriologiese aspek direk daarby betrek word. Anders gestel, God het dikwels geopenbaar wat sy volk moet doen ten opsigte van die armes. die offers en vele ander sake. Verder is Bavinck ook te min ingestel op die voortgaande aard van God se openbaring. God het nie, soos die deïste beweer, Hom teruggetrek en die aarde aan homself oorgelaat nie. Hy werk vandag nog en openbaar Homself vandag nog - daar is nie ' $n$ afsluiting van die openbaring nie. Gevolglik kan Bavinck se standpunt ook nie aanvaar word nie, omdat dit te partikularisties is - selfs skadelik vir die sending. Dit is nodig dat daar 'n veel wyer, mondiale blik moet wees en nie net 'n ekklesiologiese blik nie. Die vraag kan gestel word of God in sy openbaring die res van die wêreld wat nie die Skrif gehad het nie, altyd sonder genade verbygegaan het. Paulus se betoog kom juis neer op die teendeel en die allesoorweldigende plek van God se genade (Rom. 4:16). God gaan voort om sy genade te gee nieteenstaande die feit dat mense sy openbaring onderdruk. Vir die Jode voeg Hy nog veel meer by uit genade. In Christus kom Hy, ondanks 'n sondige mensheid, met die heerlikste selfopenbaring.

\section{GEVOIGTREKKING}

Dit sou 'n makliker pad wees om alleen die Skrif as principium theologiae te aanvaar as om die pad van die Nederlandse Geloofsbelydenis te volg. Dit is egter nie die regte pad nie. Die Skrif self (Rom. 1-4 en 10) wys ons duidelik dat dit nie die geval moet wees nie. God openbaar Homself steeds en hierdie openbaring lei tot Godskennis. Daar moet 'n weg gevind word om die voortgaande openbaring ook in die teologie te verdiskonteer al is die gevare ook hoe groot. Subjektiwisme is ook 'n wesenlike gevaar by die interpretasie van die Skrif. Die Heilige Gees is die doctor ecclesiae by sowel die interpretasie van die Skrif as van God se voortgaande openbaring. Artikel 2 van die Nederlandse Geloofsbelydenis sê saam met Romeine 1:19-21:

\footnotetext{
Ons ken Hom deur twee middele: Ten cerste deur middel van die skepping, onderhouding en regering van dic hele wêreld. Dit is immers voor ons oe soos 'n mooi bock waarin alle skepsels, groot en klein, die letters is wat ons die onsigbare dinge van God, naamlik sy ewige krag en goddelikheid, duidelik laat sien, soos die apostel Paulus sê (Rom.1:20). Al die dinge is genoegsaam om die mense te oortuig en hulle alle verontskuldiging te ontneem (De Bres, 1561:487).
} 


\section{BIBLIOGRAFIE}

BAVINCK, J.H. 1928. Gercformecrde Dogmatick 1-4. Kampen : Kok.

BERKHOF, H. 1973. Christclijk geloof. Nijkerk : Callenbach.

BERKOUWER, G.C. 1951. De algemene openbaring. Dogmatische Studiën. Kampen : Kok.

CALVYN, J. 1984. Institusic van die Christelike godsdiens. Vol. I. Vertaal deur H.W. Simpson. Potchefstroom : Calvyn Jubileum Boekcfonds.

CALVYN, J. 1959. The Epistle of Paul to the Romans. Transl. by J. Owen. Grand Rapids : Eerdmans.

DE BRES, G. 1561. Die Nederlandse Geloofsbelydenis. (Teks van die Afrikaanse Psalmbock).

DONFRIED, K.P. 1991. The Romans Debate. Revised and Expanded Edition. Edinburgh : T\&T Clark.

EDWARDS, J.R. 1992. Romans. New International Biblical Commentary, 6. Pcabody Mass. Hendricksen Publishers.

KRAEMER, H. 1938. The Christian Message in a Non-Christian World. London : Edinburgh House Press.

KRAEMER, H. 1958. Godsdienst, godsdiensten en het christelijk geloof. Nijkerk : Callenbach.

KRUGER, MA. 1983. Openbaring, geloof en geregligheid. 'n Eksegetiese ondersoek van Romeine 1-4. Pretoria : Universiteit van Pretoria. Ongepublisecrde DD proefskrif.

KRUGER, M.A. 1988. Naby jou is die Woord! Romeinc 10:8 (In Coctzec, J.C. red. Koninkryk, Gees cn Woord. Pretoria : NG Kerkbockhandel. p. 81-97.)

MOONEYHAM, S. 1974. Acts of the Holy Spirit '74. (In J.D. Douglas ed. Let the Earth Hear His Voice. Minneapolis : World Wide Publications. p. 428.)

MORRIS, L. 1988. The Epistlc to the Romans. Grand Rapids : Eerdmans.

NICHOLLS, B.J. 1988. S.v. Contextualization. (In Ferguson, S.B a.o. ed. New Dictionary of Theology. Leicester : Inter-Varsity Press. p. 164-167.)

PINNOCK, C.H. 1988. S.v. Revelation. (In Ferguson S.B. a.o. ed. New Dictionary of Theology. Leicester : Inter-Varsity Press. p. 585-587.)

POLMAN, A.D.R. 1949. (In Berkouwer G.C. \& Toornvliet (G. red. Het dogma der kerk. Groningen : Jan Haan N.V. p. 85.)

VERKUYL, J. 1975. Inleiding in de nieuwere Zendingswetenschap. Kampen : Kok. 